\title{
Peertechz
}

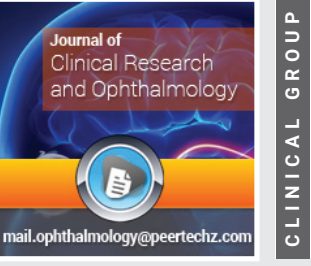

\section{On line Webinars During Time of COVID-19: Does it Increase the Clinical and Surgical Skills of Egyptian Ophthalmologists?}

Received: 22 July, 2020

Published: 28 July, 2020

*Corresponding author: Alahmady Hamad Elsamman, MD, Department of ophthalmology, Sohag Faculty Of medicine, Sohag University, Sohag, Egypt, Tel: 0021111102698; E-mail: alahmady20@yahoo.com

Keywords: Webinars; Covid19; Ophthalmologists; Pandemic

https://www.peertechz.com

\section{Check for updates}

\section{Elshimaa A Mateen Mossa ${ }^{1}$, Tasneem Mohammad Ali $^{2}$ and}

\author{
Alahmady Hammad ${ }^{3 *}$ \\ ${ }^{1}$ Department of ophthalmology, Sohag Faculty Of medicine, Sohag University, Sohag, Egypt \\ ${ }^{2}$ Department of public health and community medicine, faculty of medicine, Sohag University, Sohag, \\ Egypt \\ ${ }^{3}$ Department of ophthalmology, Sohag Faculty Of medicine, Sohag University, Sohag, Egypt
}

\begin{abstract}
Introduction: Since the appearance of COVID-19 pandemic by the end of 2019 and beginning of 2020 conferences, and events are canceled targeting the social distance to limit the spread and decrease the danger of the newly emerging virus webinars instead spread all over the world as an educational tool with no risk of communications.
\end{abstract}

Purpose: to evaluate the efficacy of webinars in increasing the clinical and surgical skills of Egyptian ophthalmologists during the time of obligatory social distancing of COVID-19.

Results: most of ophthalmologists in this survey consider the webinars is a good educational tool and hoping to progress after COVID-19 Pandemic. Most of them followed their topics of interest rather than the speaker or the organizing company and interested till the end due to the more comfortable situations.

Conclusion: Webinars are readily available technology inexpensive, beneficial experience added to the clinical and surgical skills of Egyptian ophthalmologists who are hoping to be continued even after the COVID-19 pandemic time.

\section{Introduction}

Since the appearance of COVID-19 pandemic by the end of 2019 and beginning of 2020 conferences, and events are canceled targeting the social distance to limit the spread and decrease the danger of the newly emerging virus [1]. There must be an alternative for communication and continuing the learning especially in medicine, so the trend is directed to the webinars. All we need to do is move fast and get our webinar strategy to get the benefit from and keep connected to the places virtually that are no longer available in real [2].

The word 'webinar' is composed of two compartments, 'web' and 'seminar' [3]. A webinar is an event which is held on the internet and attended exclusively by an online audience [4]. Audience or participants can follow webinars via smartphones, tablets, PC, and laptop at anywhere they are existing. They can see and hear the speaker [5]. Webinar allows various interactive opportunities, such as asking a question, Chatting, Poll, Survey and Tests [6].

In this study we aimed to evaluate the efficacy of webinars in increasing the clinical and surgical skills of Egyptian ophthalmologists during the time of quarantine due to pandemic of COVID-19.

\section{Materials and methods}

The study is a clinical observational survey "evaluative 
type" conducted in Egypt to investigates the efficacy of webinars from perspective of Egyptian ophthalmologist, whether it increase their clinical and surgical skills or not.

\section{Inclusion criteria}

All Egyptian ophthalmologists enrolled in one or more Webinars were invited through sending the poll and asking them to participate in the online survey through official and non-official online groups for Egyptian ophthalmologists (e.g., Egyptian association of pediatric ophthalmology and strabismus group, EPK \& NPK group, Upper Egypt ophthalmologists and others of official and non-official ophthalmological groups).

\section{Exclusion criteria}

Egyptian ophthalmologists who did not attend webinars during the period of quarantine due to COVID-19.130 physicians completed the survey. participants reported their governorates, place of work, age, and their academic degree. Participant were also asked about the extent to which webinars increased their clinical and surgical skills. Responses were rated from very bad to excellent. Their participation was voluntary and anonymous. The study was approved by Sohag faculty of medicine and Sohag University Ethics Committee and the tenets of Helsinki declaration were followed.

\section{Statistical analysis}

Data was analyzed using SPSS computer program version 25. Quantitative data was expressed as means \pm standard deviation, median and IQ range. Qualitative data was expressed as number and percentage. A $5 \%$ level was chosen as a level of significance in all statistical tests used in the study.

\section{Results}

The final valid sample comprised a total of 130 ophthalmologist. $87(66.9 \%)$ were males while $43(33.1 \%)$ were females. Their mean age was $43.3+9.6$ for males and $34.7+6.1$ for females and there was a highly statistically significant difference between the mean ages of males and females $\mathrm{p}<0.0001$. Most of participants have a doctorate degree $(60 \%)$, then came the master's degree $(31.5 \%)$ followed by bachelor's degree $(5.4 \%)$ and Diploma (3.1\%). Participated ophthalmologists distributed allover Egypt governorates, and their governmental distribution demonstrated in (Figure 1).

Physicians answered the survey questions and the results were that about $(75 \%)$ of them were interested on the topic rather than speaker nor the company organizing the webinar (Figure 2). About (34\%) of the participants found that webinars are better than the real regular conferences (Figure 3). There was a statistically significant difference between male and female responses on this question ( $p$ value $=0.05$ ). Most of them usually keep their attention and concentration to the end (41\%) (Figure 4). About (56\%) of participants answered that webinars were good in increasing their clinical skills as regard diagnosis and management (Figure 5). Also 63\% answered that webinars were good in increasing their surgical skills (Figure 6). Although (55\%) stated that increased frequency of webinars decreased their benefit but most of them " $80 \%$ of the participants" encouraging the webinars to be continued even after the end of the COVID-19 pandemic ( $75 \%$ of males and $90 \%$ of females) Table 1 and (Figures 7,8).

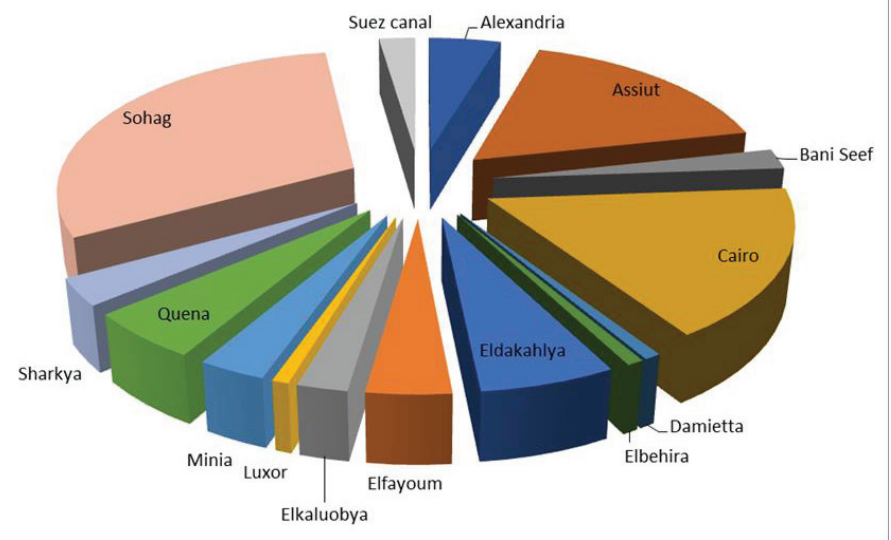

Figure 1: Governmental distribution of the studied physicians.

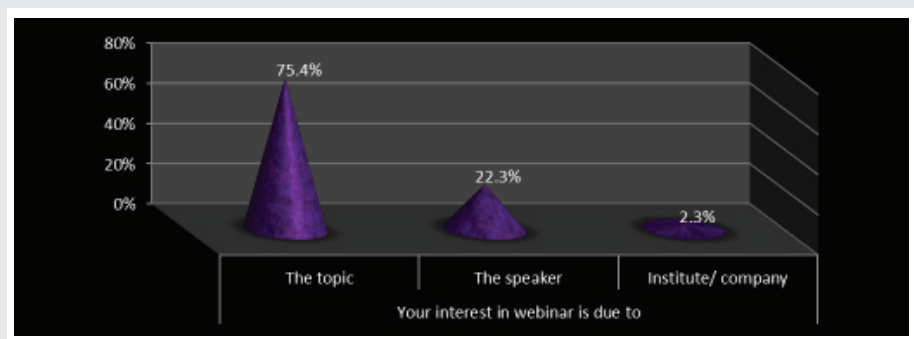

Figure 2: Interest in webinars is mostly to the topic.

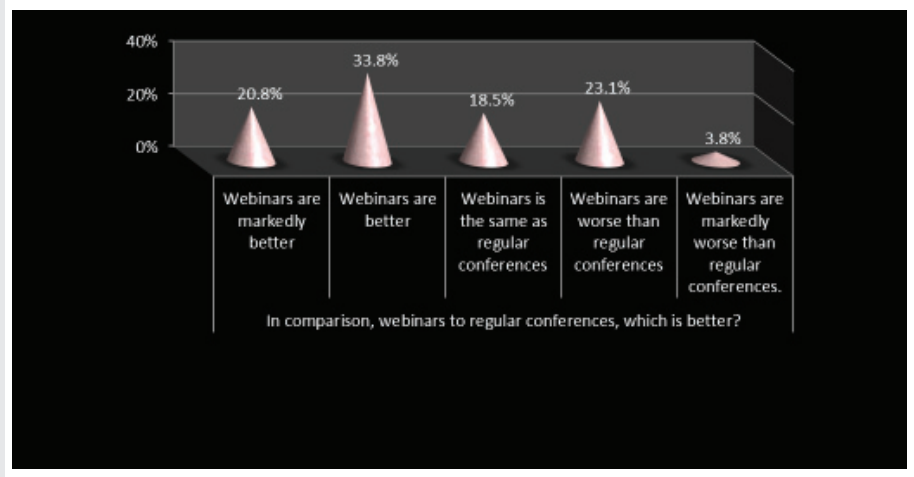

Figure 3: Comparison between webinars to regular conferences, showing that webinars are more preferred.

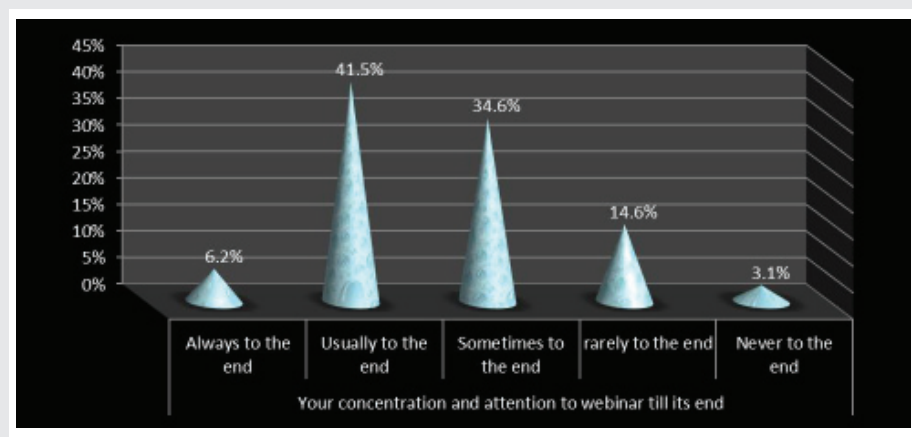

Figure 4: Concentration and attention to which extent the participants could keep.

Citation: Mateen Mossa EA, Ali TM, Hammad A (2020) On line Webinars During Time of COVID-19: Does it Increase the Clinical and Surgical Skills of Egyptian Ophthalmologists? J Clin Res Ophthalmol. 7(2): 075-080. DOI: https://dx.doi.org/10.17352/2455-1414.000076 


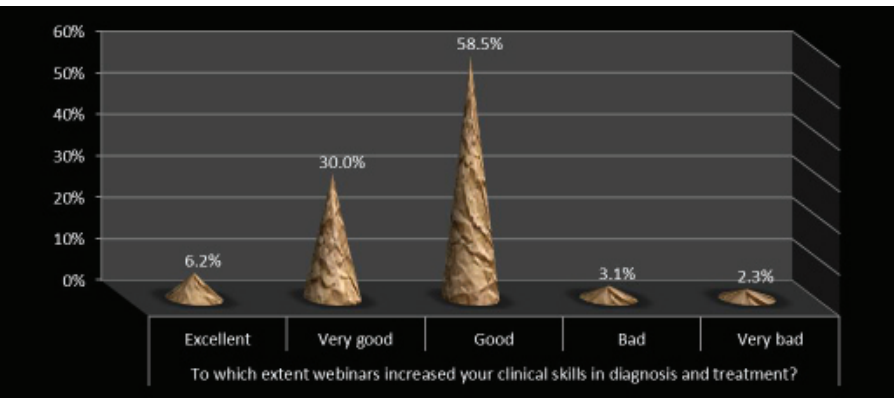

Figure 5: Effect of webinars on clinical skills in diagnosis and treatment.

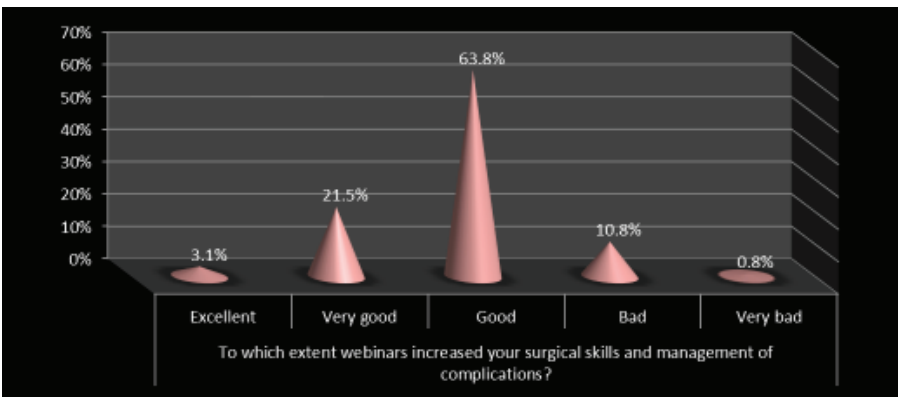

Figure 6: Effect of webinars on increasing the surgical skills of the participants.
There was no significant difference between males and females answers on most of questions Table 1. Different academic degrees and different age groups mostly have the same opinion regarding the answers of the questions of the survey Tables 2,3.

\section{Discussion}

This study aimed to evaluate to which extent the online scientific webinars during the era of COVID-19 pandemic improved knowledge (clinical and surgical skills) for Egyptian ophthalmologists and to assess their satisfaction.

Comparing results of the survey between both genders and according to different age groups, below and above age of forty there was no significant difference which was consistent with Hager Khechine et al, regarding the gender but different regarding the age, as they stated that younger students were more concerned than older students in their study "UTAUT Model for Blended Learning: The Role of Gender and Age in the Intention to Use Webinars' [7].

$33 \%$ participants stated that the webinars are better than regular actual conferences and this was consistent with the

Table 1: Responses of the physicians according to sex differentiation.

\begin{tabular}{|c|c|c|c|c|c|c|c|c|}
\hline Questions & Options & males & females & total & p-value & & & \\
\hline \multirow{3}{*}{ Your interest in webinar is due to } & The topic & 66 & $75.9 \%$ & 32 & $74.4 \%$ & 98 & $75.4 \%$ & \multirow{3}{*}{0.9} \\
\hline & The speaker & 19 & $21.8 \%$ & 10 & $23.3 \%$ & 29 & $22.3 \%$ & \\
\hline & Institute/ company & 2 & $2.3 \%$ & 1 & $2.3 \%$ & 3 & $2.3 \%$ & \\
\hline \multirow{5}{*}{$\begin{array}{l}\text { In comparison, webinars to regular conferences, } \\
\text { which is better? }\end{array}$} & Webinars are markedly better & 13 & $14.9 \%$ & 14 & $32.6 \%$ & 27 & $20.8 \%$ & \multirow{5}{*}{0.05} \\
\hline & Webinars are better & 28 & $32.2 \%$ & 16 & $37.2 \%$ & 44 & $33.8 \%$ & \\
\hline & $\begin{array}{l}\text { Webinars is the same as regular } \\
\text { conferences }\end{array}$ & 17 & $19.5 \%$ & 7 & $16.3 \%$ & 24 & $18.5 \%$ & \\
\hline & $\begin{array}{l}\text { Webinars are worse than regular } \\
\text { conferences }\end{array}$ & 24 & $27.6 \%$ & 6 & $14.0 \%$ & 30 & $23.1 \%$ & \\
\hline & $\begin{array}{l}\text { Webinars are markedly worse } \\
\text { than regular conferences. }\end{array}$ & 5 & $5.7 \%$ & 0 & $0.0 \%$ & 5 & $3.8 \%$ & \\
\hline \multirow{5}{*}{$\begin{array}{l}\text { Your concentration and attention to webinar till } \\
\text { its end }\end{array}$} & Always to the end & 5 & $5.7 \%$ & 3 & $7.0 \%$ & 8 & $6.2 \%$ & \multirow{5}{*}{0.3} \\
\hline & Usually to the end & 31 & $35.6 \%$ & 23 & $53.5 \%$ & 54 & $41.5 \%$ & \\
\hline & Sometimes to the end & 34 & $39.1 \%$ & 11 & $25.6 \%$ & 45 & $34.6 \%$ & \\
\hline & rarely to the end & 14 & $16.1 \%$ & 5 & $11.6 \%$ & 19 & $14.6 \%$ & \\
\hline & Never to the end & 3 & $3.4 \%$ & 1 & $2.3 \%$ & 4 & $3.1 \%$ & \\
\hline \multirow{5}{*}{$\begin{array}{l}\text { To which extent webinars increased your clinical } \\
\text { skills in diagnosis and treatment? }\end{array}$} & Excellent & 2 & $2.3 \%$ & 6 & $14.0 \%$ & 8 & $6.2 \%$ & \multirow{5}{*}{0.07} \\
\hline & Very good & 30 & $34.5 \%$ & 9 & $20.9 \%$ & 39 & $30.0 \%$ & \\
\hline & Good & 51 & $58.6 \%$ & 25 & $58.1 \%$ & 76 & $58.5 \%$ & \\
\hline & Bad & 2 & $2.3 \%$ & 2 & $4.7 \%$ & 4 & $3.1 \%$ & \\
\hline & Very bad & 2 & $2.3 \%$ & 1 & $2.3 \%$ & 3 & $2.3 \%$ & \\
\hline \multirow{5}{*}{$\begin{array}{l}\text { To which extent webinars increased } \\
\text { your surgical skills and management of } \\
\text { complications? }\end{array}$} & Excellent & 2 & $2.3 \%$ & 2 & $4.7 \%$ & 4 & $3.1 \%$ & \multirow{5}{*}{0.4} \\
\hline & Very good & 19 & $21.8 \%$ & 9 & $20.9 \%$ & 28 & $21.5 \%$ & \\
\hline & Good & 58 & $66.7 \%$ & 25 & $58.1 \%$ & 83 & $63.8 \%$ & \\
\hline & Bad & 8 & $9.2 \%$ & 6 & $14.0 \%$ & 14 & $10.8 \%$ & \\
\hline & Very bad & 0 & $0.0 \%$ & 1 & $2.3 \%$ & 1 & $0.8 \%$ & \\
\hline \multirow{3}{*}{$\begin{array}{l}\text { Do you think increased number of webinars } \\
\text { affect their benefits and values negatively }\end{array}$} & Yes & 51 & $58.6 \%$ & 21 & $48.8 \%$ & 72 & $55.4 \%$ & \multirow{3}{*}{0.4} \\
\hline & No & 14 & $16.1 \%$ & 7 & $16.3 \%$ & 21 & $16.2 \%$ & \\
\hline & To some extent & 22 & $25.3 \%$ & 15 & $34.9 \%$ & 37 & $28.5 \%$ & \\
\hline \multirow{2}{*}{$\begin{array}{l}\text { Do you like to continue Webinars regularly after } \\
\text { covid-19 pandemic? }\end{array}$} & Yes & 66 & $75.9 \%$ & 39 & $90.7 \%$ & 105 & $80.8 \%$ & \multirow{2}{*}{0.04} \\
\hline & No & 21 & $24.1 \%$ & 4 & $9.3 \%$ & 25 & $19.2 \%$ & \\
\hline \multicolumn{9}{|l|}{$\begin{array}{l}\text { Data presented as number and column percentage } \\
\star \star ~ P \text { value was calculated by Pearson Chi square Test }\end{array}$} \\
\hline & & & & & & & & 077 \\
\hline
\end{tabular}

Citation: Mateen Mossa EA, Ali TM, Hammad A (2020) On line Webinars During Time of CoVID-19: Does it Increase the Clinical and Surgical Skills of Egyptian Ophthalmologists? J Clin Res Ophthalmol. 7(2): 075-080. DOI: https://dx.doi.org/10.17352/2455-1414.000076 


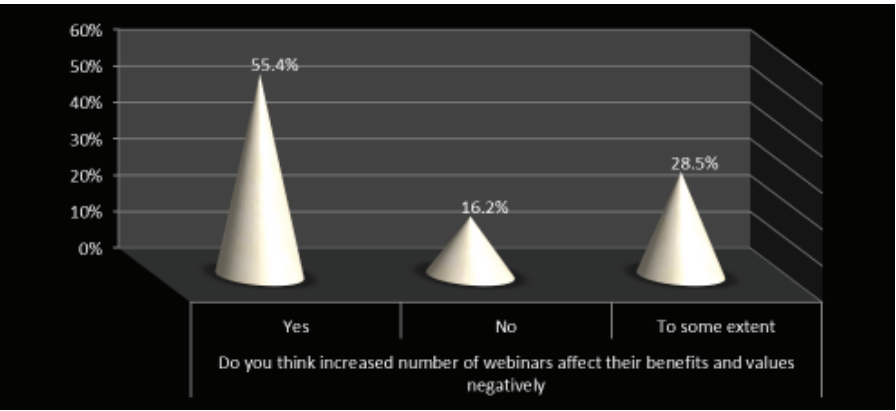

Figure 7: Increased number of webinars impact on the participants.

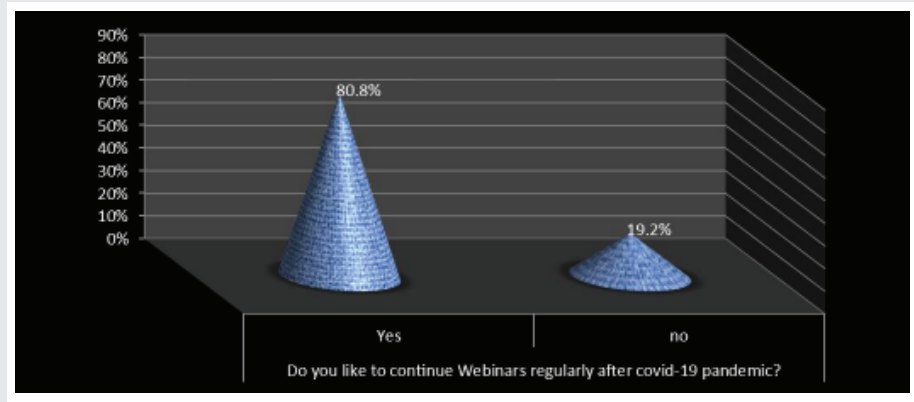

Figure 8: The participants opinion about continuing webinars after Covid-19 pandemic. results of W.Paul MicKinney who stated that the attendee of the health workers were satisfied with Internet-based training and they feel a measurable changes in their knowledge and behavior [8].

$58.5 \%, 63.8 \%$ were the results of the participants for (GOOD answer) for improving clinical and surgical skills which implicit that they got benefit from the online webinars during the period of pandemic and this is consistent with Christian Ebner and Andreas Gegenfurtner in their study " Learning and Satisfaction in Webinar, Online, and Face-to-Face Instruction": it was a Meta-Analysis study concluding that learning outcomes were better in webinars compared to faceto-face conferences [9].

Most of the participants keep attention and maintain concentration usually to the end of the webinar and this could be correlated to the length of it. Webinar duration should not to be more than one hour, as it is found that for attendee to be actively engaged to the webinars, and to get information away from the presentations, the concept of "brain-based learning" states that learning sessions should be 2ominutes or less to get the maximum benefit [10]. It also could be attributed to the days of the week at which the webinars held as it is proved

Table 2: Responses of the physicians according to academic degree differentiation.

\begin{tabular}{|c|c|c|c|c|c|c|c|c|c|}
\hline & Questions & & helor & & loma & & ster & & orate \\
\hline \multirow{3}{*}{ Your interest in webinar is due to } & The topic & 5 & $3.8 \%$ & 2 & $1.5 \%$ & 32 & $24.6 \%$ & 59 & $45.4 \%$ \\
\hline & The speaker & 2 & $1.5 \%$ & 2 & $1.5 \%$ & 7 & $5.4 \%$ & 18 & $13.8 \%$ \\
\hline & Institute/ company & 0 & $0.0 \%$ & 0 & $0.0 \%$ & 2 & $1.5 \%$ & 1 & $0.8 \%$ \\
\hline \multirow{5}{*}{$\begin{array}{l}\text { In comparison, webinars to regular conferences, which is } \\
\text { better? }\end{array}$} & Webinars are markedly better & 2 & $1.5 \%$ & 1 & $0.8 \%$ & 9 & $6.9 \%$ & 15 & $11.5 \%$ \\
\hline & Webinars are better & 4 & $3.1 \%$ & 0 & $0.0 \%$ & 15 & $11.5 \%$ & 25 & $19.2 \%$ \\
\hline & $\begin{array}{l}\text { Webinars is the same as regular } \\
\text { conferences }\end{array}$ & 1 & $0.8 \%$ & 3 & $2.3 \%$ & 9 & $6.9 \%$ & 11 & $8.5 \%$ \\
\hline & $\begin{array}{l}\text { Webinars are worse than regular } \\
\text { conferences }\end{array}$ & 0 & $0.0 \%$ & 0 & $0.0 \%$ & 6 & $4.6 \%$ & 24 & $18.5 \%$ \\
\hline & $\begin{array}{l}\text { Webinars are markedly worse than } \\
\text { regular conferences. }\end{array}$ & 0 & $0.0 \%$ & 0 & $0.0 \%$ & 2 & $1.5 \%$ & 3 & $2.3 \%$ \\
\hline \multirow{5}{*}{ Your concentration and attention to webinar till its end: } & Always to the end & 0 & $0.0 \%$ & 0 & $0.0 \%$ & 3 & $2.3 \%$ & 5 & $3.8 \%$ \\
\hline & Usually to the end & 6 & $4.6 \%$ & 1 & $0.8 \%$ & 17 & $13.1 \%$ & 30 & $23.1 \%$ \\
\hline & Sometimes to the end & 1 & $0.8 \%$ & 3 & $2.3 \%$ & 14 & $10.8 \%$ & 27 & $20.8 \%$ \\
\hline & rarely to the end & 0 & $0.0 \%$ & 0 & $0.0 \%$ & 5 & $3.8 \%$ & 14 & $10.8 \%$ \\
\hline & Never to the end & 0 & $0.0 \%$ & 0 & $0.0 \%$ & 2 & $1.5 \%$ & 2 & $1.5 \%$ \\
\hline \multirow{5}{*}{$\begin{array}{l}\text { To which extent webinars increased your clinical skills in } \\
\text { diagnosis and treatment? }\end{array}$} & Excellent & 0 & $0.0 \%$ & 0 & $0.0 \%$ & 6 & $4.6 \%$ & 2 & $1.5 \%$ \\
\hline & Very good & 5 & $3.8 \%$ & 1 & $0.8 \%$ & 8 & $6.2 \%$ & 25 & $19.2 \%$ \\
\hline & Good & 2 & $1.5 \%$ & 3 & $2.3 \%$ & 24 & $18.5 \%$ & 47 & $36.2 \%$ \\
\hline & Bad & 0 & $0.0 \%$ & 0 & $0.0 \%$ & 2 & $1.5 \%$ & 2 & $1.5 \%$ \\
\hline & Very bad & 0 & $0.0 \%$ & 0 & $0.0 \%$ & 1 & $0.8 \%$ & 2 & $1.5 \%$ \\
\hline \multirow{5}{*}{$\begin{array}{l}\text { To which extent webinars increased your surgical skills and } \\
\text { management of complications? }\end{array}$} & Excellent & 0 & $0.0 \%$ & 0 & $0.0 \%$ & 2 & $1.5 \%$ & 2 & $1.5 \%$ \\
\hline & Very good & 4 & $3.1 \%$ & 0 & $0.0 \%$ & 7 & $5.4 \%$ & 17 & $13.1 \%$ \\
\hline & Good & 3 & $2.3 \%$ & 4 & $3.1 \%$ & 25 & $19.2 \%$ & 51 & $39.2 \%$ \\
\hline & Bad & 0 & $0.0 \%$ & 0 & $0.0 \%$ & 7 & $5.4 \%$ & 7 & $5.4 \%$ \\
\hline & Very bad & 0 & $0.0 \%$ & 0 & $0.0 \%$ & 0 & $0.0 \%$ & 1 & $0.8 \%$ \\
\hline \multirow{3}{*}{$\begin{array}{l}\text { Do you think increased number of webinars affect their } \\
\text { benefits and values negatively }\end{array}$} & Yes & 3 & $2.3 \%$ & 2 & $1.5 \%$ & 24 & $18.5 \%$ & 43 & $33.1 \%$ \\
\hline & No & 1 & $0.8 \%$ & 2 & $1.5 \%$ & 6 & $4.6 \%$ & 12 & $9.2 \%$ \\
\hline & To some extent & 3 & $2.3 \%$ & 0 & $0.0 \%$ & 11 & $8.5 \%$ & 23 & $17.7 \%$ \\
\hline \multirow{2}{*}{$\begin{array}{l}\text { Do you like to continue Webinars regularly after covid-19 } \\
\qquad \text { pandemic? }\end{array}$} & Yes & 7 & $5.4 \%$ & 4 & $3.1 \%$ & 35 & $26.9 \%$ & 59 & $45.4 \%$ \\
\hline & No & 0 & $0.0 \%$ & 0 & $0.0 \%$ & 6 & $4.6 \%$ & 19 & $14.6 \%$ \\
\hline
\end{tabular}


Table 3: Comparison between responses of the physicians among age groups.

\begin{tabular}{|c|c|c|c|c|c|c|}
\hline & \multirow[t]{2}{*}{ Questions } & \multicolumn{2}{|c|}{ More than 40 yrs. No= (62) } & \multicolumn{2}{|c|}{$\begin{array}{l}\text { Less than } 40 \text { yrs. } \\
\text { No. }=(68)\end{array}$} & \multirow[t]{2}{*}{ P value } \\
\hline & & No. & $\%$ & No. & $\%$ & \\
\hline \multirow{3}{*}{ Your interest in webinar is due to } & The topic & 47 & $75.8 \%$ & 51 & $75.0 \%$ & \multirow{3}{*}{0.8} \\
\hline & The speaker & 14 & $22.6 \%$ & 15 & $22.1 \%$ & \\
\hline & Institute/ company & 1 & $1.6 \%$ & 2 & $2.9 \%$ & \\
\hline \multirow{5}{*}{$\begin{array}{l}\text { In comparison, webinars to regular conferences, which is } \\
\text { better? }\end{array}$} & Webinars are markedly better & 10 & $16.1 \%$ & 17 & $25.0 \%$ & \multirow{5}{*}{0.4} \\
\hline & Webinars are better & 21 & $33.9 \%$ & 23 & $33.8 \%$ & \\
\hline & $\begin{array}{l}\text { Webinars is the same as regular } \\
\text { conferences }\end{array}$ & 10 & $16.1 \%$ & 14 & $20.6 \%$ & \\
\hline & $\begin{array}{l}\text { Webinars are worse than regular } \\
\text { conferences }\end{array}$ & 18 & $29.0 \%$ & 12 & $17.6 \%$ & \\
\hline & $\begin{array}{l}\text { Webinars are markedly worse than regular } \\
\text { conferences. }\end{array}$ & 3 & $4.8 \%$ & 2 & $2.9 \%$ & \\
\hline \multirow{5}{*}{ Your concentration and attention to webinar till its end: } & Always to the end & 5 & $8.1 \%$ & 3 & $4.4 \%$ & \multirow{5}{*}{0.2} \\
\hline & Usually to the end & 23 & $37.1 \%$ & 31 & $45.6 \%$ & \\
\hline & Sometimes to the end & 20 & $32.3 \%$ & 25 & $36.8 \%$ & \\
\hline & rarely to the end & 13 & $21.0 \%$ & 6 & $8.8 \%$ & \\
\hline & Never to the end & 1 & $1.6 \%$ & 3 & $4.4 \%$ & \\
\hline \multirow{5}{*}{$\begin{array}{l}\text { To which extent webinars increased your clinical skills in } \\
\text { diagnosis and treatment? }\end{array}$} & Excellent & 2 & $3.2 \%$ & 6 & $8.8 \%$ & \multirow{5}{*}{0.5} \\
\hline & Very good & 22 & $35.5 \%$ & 17 & $25.0 \%$ & \\
\hline & Good & 35 & $56.5 \%$ & 41 & $60.3 \%$ & \\
\hline & Bad & 2 & $3.2 \%$ & 2 & $2.9 \%$ & \\
\hline & Very bad & 1 & $1.6 \%$ & 2 & $2.9 \%$ & \\
\hline \multirow{5}{*}{$\begin{array}{l}\text { To which extent webinars increased your surgical skills and } \\
\text { management of complications? }\end{array}$} & Excellent & 2 & $3.2 \%$ & 2 & $2.9 \%$ & \multirow{5}{*}{0.8} \\
\hline & Very good & 12 & $19.4 \%$ & 16 & $23.5 \%$ & \\
\hline & Good & 40 & $64.5 \%$ & 43 & $63.2 \%$ & \\
\hline & Bad & 7 & $11.3 \%$ & 7 & $10.3 \%$ & \\
\hline & Very bad & 1 & $1.6 \%$ & $0^{\mathrm{a}}$ & $0.0 \%$ & \\
\hline \multirow{3}{*}{$\begin{array}{l}\text { Do you think increased number of webinars affect their } \\
\text { benefits and values negatively }\end{array}$} & Yes & 33 & $53.2 \%$ & 39 & $57.4 \%$ & \multirow{3}{*}{0.8} \\
\hline & No & 11 & $17.7 \%$ & 10 & $14.7 \%$ & \\
\hline & To some extent & 18 & $29.0 \%$ & 19 & $27.9 \%$ & \\
\hline \multirow{2}{*}{$\begin{array}{l}\text { Do you like to continue Webinars regularly after covid-19 } \\
\text { pandemic? }\end{array}$} & Yes & 47 & $75.8 \%$ & 58 & $85.3 \%$ & \multirow{2}{*}{0.1} \\
\hline & No & 15 & $24.2 \%$ & 10 & $14.7 \%$ & \\
\hline
\end{tabular}

that Tuesdays, Wednesdays, and Thursdays are the best for live events in countries where Saturday and Sunday are the week end. In Egypt where Friday and Saturday are the weekend it could be Monday, Tuesday and Wednesday are the best for holding live events. Timing of the event is also important and it could be that the earlier the better, 11 am may be the best time [11].

\section{Conclusion and recommendations}

Webinars are readily available technology inexpensive, beneficial added to the clinical and surgical skills of Egyptian ophthalmologists who are hoping to be continued even after the COVID-19 pandemic time.

We recommend that webinar events should be modified to attract more audience and encourage them to engage to it and maintain their attention and concentration level up to the end. It is important to select the appropriate days, as we recommend Monday, Tuesday, and Wednesday, away from the weekend, day after and day before it. The time of live events also is important, 11am while the attendee still active and can get information. It is advisable to the speakers to register the participants via their email to be able to recommunicate with answering their questions and send them evaluation survey to be able to plane for more attractive and successful next scientific webinars. Spacing between successive webinars is important for the audience not to get pored and keeping the webinars beneficial and interesting. end with a summary of the presented information and the speaker should send the attendee an evaluation form by their emails known via their registration immediately after the event and continue to check the participants response to the evaluation for two weeks in order to improve his upcoming webinar and this wasn't the case in most of webinars held during months of COVID-19 which could be correlated to the answer of the participants of the survey that increased frequency of webinars decrease their benefits $[11,12]$.

Limitations of the study, we could assess the efficacy of the webinars subjectively through the answers of the participants to the questionnaire, further studies for objective evaluation is needed as pre and post test studies for assessing knowledge and skills.

\section{Competing interests}

No conflict of interest. There is neither a financial 
relationship nor sponsorship with any organization to be declared. The authors have full control of all primary data and they agree to allow British Journal of ophthalmology to review their data if required.

\section{Acknowledgment}

We would like to express our special thanks of gratitude to our colleagues and professors who answered and submitted the questionnaire as well the official and non-official ophthalmological groups (Egyptian association of pediatric ophthalmology and strabismus group, EPK \& NPK group, Upper Egypt ophthalmologists group, scientific activity group, Sohag ophthalmology department group and Modern eye center group) which gave us the golden opportunity to do this research.

\section{References}

1. Vannabouathong C, Devji T, Ekhtiari S, Chang Y, Phillips SA, et al. (2020) Novel coronavirus COVID-19: current evidence and evolving strategies The Journal of bone and Joint Surgery American 102: 734-744. Link: https://bit.ly/2WZx2Vb

2. Franklin T, Harmelen M (2007) Web 2.0 for content for learning and teaching in higher education. Link: https://bit.ly/2BxAgry

3. Kapp KM, Wingate L (2012) Designing, Marketing, and Delivering an Effective Webinar: Guidelines Based on Research and Practice. Journal of Applied Learning Technology 2: 16. Link: https://bit.ly/305mYw6
4. Rao PS (2019) Webinars as Instructional Tools in English Language Context. Literary Endeavour 152.

5. Barbosa TJ, Barbosa MJ (2019) Zoom: An Innovative Solution For The LiveOnline Virtual Classroom. HETS Online Journal 9. Link: https://bit.ly/3f5fBZM

6. Zoumenou V, Sigman-Grant M, Coleman G, Malekian F, Zee JM, et al. (2015) Identifying best practices for an interactive webinar. Journal of Family \& Consumer Sciences. 107: 62-69. Link: https://bit.ly/3fORgnL

7. Khechine H, Lakhal S, Pascot D, Bytha A (2014) UTAUT model for blended learning: The role of gender and age in the intention to use webinars. Interdisciplinary Journal of E-Learning and Learning Objects 10: 33-52. Link: https://bit.ly/3hGklqw

8. McKinney WP (2017) Assessing the Evidence for the Educational Efficacy of Webinars and Related Internet-Based Instruction. Pedagogy in Health Promotion 3: 47S-51S. Link: https://bit.ly/2Eood0V

9. Gegenfurtner A, Ebner C (2019) Webinars in higher education and professional training: A meta-analysis and systematic review of randomized controlled trials. Educational Research Review 28: 100293. Link: https://bit.ly/3hCTbRd

10. Bedford N (2016) Webinar Best Practices. Link: https://bit.ly/2Dahx61

11. Lande LM (2011) Webinar best practices: From invitation to evaluation: Citeseer.

12. Guanci G (2010) Best practices for webinars. Creative nursing 16: 119-121 Link: https://bit.ly/2P1tu0w
Discover a bigger Impact and Visibility of your article publication with

Peertechz Publications

\section{Highlights}

* Signatory publisher of ORCID

* Signatory Publisher of DORA (San Francisco Declaration on Research Assessment)

* Articles archived in worlds' renowned service providers such as Portico, CNKI, AGRIS, TDNet, Base (Bielefeld University Library), CrossRef, Scilit, J-Gate etc.

* Journals indexed in ICMJE, SHERPA/ROMEO, Google Scholar etc.

* OAI-PMH (Open Archives Initiative Protocol for Metadata Harvesting)

* Dedicated Editorial Board for every journal

* Accurate and rapid peer-review process

* Increased citations of published articles through promotions

* Reduced timeline for article publication

Submit your articles and experience a new surge in publication services (https://www.peertechz.com/submission).

Peertechz journals wishes everlasting success in your every endeavours.

Copyright: (c) 2020 Mateen Mossa EA, et al. This is an open-access article distributed under the terms of the Creative Commons Attribution License, which permits unrestricted use, distribution, and reproduction in any medium, provided the original author and source are credited. 